\title{
Comparison of two artificial diets to rear Elaphria agrotina
}

\author{
Pollyanna Nunes de Otanásio ${ }^{1}$ Ludgero Cardoso Galli Vieira $^{1}$ Vânia Ferreira Roque-Specht ${ }^{1}$ \\ Silvana Vieira de Paula-Moraes ${ }^{2}$ Priscila Maria Colombo da Luz ${ }^{1}$ Alexandre Specht ${ }^{1,3^{*}} \mathcal{C}$
}

\footnotetext{
'Programa de Pós-graduação em Ciências Ambientais (PPGCA), Faculdade UnB Planaltina (FUP), Universidade de Brasília (UnB), Planaltina, DF, Brasil. ${ }^{2}$ Department of Entomology and Nematology, University of Florida, West Florida Research and Education Center, Jay, FL, USA.

${ }^{3}$ Embrapa Cerrados, BR 020, Km 18, Caixa Postal 08223, 73310-970, Planaltina, DF, Brasil. E-mail: alexandre.specht@embrapa.br. *Corresponding author.
}

ABSTRACT: Given the increasing importance of Elaphria agrotina (Guenée) (Lepidoptera: Noctuidae) in corn crops, especially in the Brazilian Savannah biome, the present research aimed to study its development and survival on Greene's and Poitout \& Bues's artificial diets $\left(25 \pm 1^{\circ} \mathrm{C}\right.$, $70 \pm 10 \%$ relative humidity [RH] and $12 \mathrm{~h}$ photophase). Poitout \& Bues's diet was more suitable than Greene's diet, providing higher survival percent (77.51\% vs. 5.57\%), lower development time (49.81 days vs. 55.24 days) and higher fecundity (167.65 vs. 84.9 eggs), respectively. All the caterpillars reared on Poitout \& Bues's diet passed through six instars, while almost half of the larvae reared on Greene's diet went through one less instar stage. Regarding the main reproductive parameters, higher average time of generation (T) and lower values of net rates of reproduction $($ Ro), and increased (rm) intrinsic and finite reason of increase ( $\lambda)$, were observed for larvae reared on Greene's diet. Results presented in this study indicated that Poitout \& Bues's diet is more suitable for maintenance of colonies of E. agrotina as compared to Greene's diet. Key words: row crops, adequacy, biology, lepidopteran-pests, maintenance of colonies.

Comparação de duas dietas artificiais para criação de Elaphria agrotina

RESUMO: Com a crescente importância de Elaphria agrotina (Guenée) (Lepidoptera: Noctuidae) em cultivos de milho, especialmente no Bioma Cerrado, o presente trabalho objetivou comparar o seu desenvolvimento e sobrevivência em dieta artificial de Greene e Poitout \& Bues $\left(25 \pm 1{ }^{\circ} \mathrm{C}, 70 \pm 10 \%\right.$ umidade relativa [UR] e fotofase de 12h). A dieta de Poitout \& Bues foi mais adequada que a dieta de Grenne, proporcionando maior sobrevivência (77.51\% e 5.57\%), menor tempo de desenvolvimento (49.81 dias e 55.24 dias) e maior fecundidade (167.65 ovos e 84.9 ovos), respectivamente. Todas as lagartas alimentadas com dieta de Poitout \& Bues passaram por seis instares, enquanto que praticamente metade das provenientes da dieta de Greene passou por um instar a menos. Lagartas alimentadas com dieta de Greene, apresentaram maior valor do tempo médio de cada geração (T) e menores valores das taxas líquida de reprodução (Ro), intrínseca de aumento (rm) e razão finita diária de aumento ( $\lambda$ ). Os resultados deste estudo indicam a recomendação da dieta de Poitout \& Bues para manutenção de colônias e criação massal de E. agrotina quando comparada com a dieta de Greene.

Palavras-chave: culturas anuais, adequação, biologia, lepidópteros-praga, manutenção de colônias de insetos.

\section{INTRODUCTION}

Elaphria agrotina (Guenée, 1852) (Lepidoptera: Noctuidae) is a small moth whose larvae have a feeding preference for dry plant tissues. This feeding behavior causes damage to several crops, with the biggest damage observed in grain crops, such corn. Larvae of this species feed on the cob base causing toppling. In soybean, the larvae feed on pods and dry seeds (SPECHT et al., 2014), while in pineapple, they feed on the base of the bracts (GALLO et al., 2002).

This species is distributed across all American continents, especially among the latitudes $30^{\circ}$ North and South (e.g. TARRAGÓ et al., 1975, SPECHT et al., 2004; 2014; HEPPNER, 2007).
Below parallel $30^{\circ}$ South, the entomologist Dr. C.M. Biezanko classified this species as "common" and in 1951 reported an outbreak in Pelotas municipality, Rio Grande do Sul, Brazil (SPECHT et al., 2004). In the last crop seasons, farmers reported outbreaks of this species across several sites of the Brazilian Savannah. Samples collected mainly from corn and soybean fields were identified as E. agrotina (Laboratory of Entomology of Embrapa Cerrados). Samples are from the West of Bahia and MATOPIBA region (Maranhão, Tocantins, Piauí and Bahia States, Brazil).

Considering the increasing economic importance of E. agrotina, especially in Brazilian Savannah biome, the present research intended to evaluate the E. agrotina development under two 
artificial diets of broad use for Noctuidae rearing, aiming to establish colony for bioassays to study the ecology of this species.

\section{MATERIALS AND METHODS}

Elaphria agrotina adults $(\mathrm{n}=10)$ were collected from the Embrapa Cerrados Experimental Station (15 $36^{\prime} 7.1^{\prime \prime} \mathrm{S} ; 47^{\circ} 42^{\prime} 46.67^{\prime \prime} \mathrm{W}, 1000 \mathrm{~m}$, a.s.1.) using light trap. They were kept in metallic cages covered with $30 \mathrm{~cm}^{2}$ catching nets and an adult diet (105 honey in water solution). Corn leaves' bouquets were available to stimulate oviposition. A total of 1,348 eggs were collected from the cages with female adults and two colonies were established to test the artificial diets of Greene (GREENE et al., 1976) and Poitout \& Bues (POITOUT \& BUES 1974) (Table 1). Sixty hundred eighty larvae were used to establish each colony. Because this species does not present cannibalistic behavior, 10 larvae each were kept in $30 \mathrm{~mL}$ container.

The comparative developmental study on the two different diets was performed with neonates from the second generation of each colony reared on Greene's and Poitout and Bues's artificial diets. The experiment was conducted under controlled conditions $\left(25 \pm 1^{\circ} \mathrm{C}, 70 \pm 10 \%\right.$ relative humidity [RH] and $12 \mathrm{~h}$ of photophase), being 200 eggs for each diet, individualized on the first day after oviposition by cutting part of the substrate and placing it on damp filter papers, which were in turn placed in petri dishes until larval eclosion.

After larval eclosion, the neonates were individualized in plastic containers with transparent lids $(30 \mathrm{~mL})$ containing $5 \mathrm{~mL}$ of diet. The containers were observed daily to identify changes in the larval instars. After feeding was ceased and size reduction initiated (which is the characteristic of the pre-pupal period), larvae were transferred to other containers with autoclaved vermiculite to stimulate the larvae to build the pupal chamber.

Pupae were kept in the same container with damp vermiculite. On the second day after metamorphosis, gender identification was performed based on BUTT \& CANTU (1962) and each pupa was weighted on semi analytical scale (precision of one-hundredth of a gram).

Adults from the same colony and those that emerged on the same day were coupled and kept in PVC cages (dimension: $16 \mathrm{~cm}$ diameter x $21 \mathrm{~cm}$ height). A total of 20 couples were formed with individuals from the Poitout \& Bues's diet and ten couples were formed with individuals from the Greene's diet. Interior of each cage was lined with craft paper, which was replaced every $24 \mathrm{~h}$ for egg counting.

The duration of each developmental stage (including the pre-pupal period) and the pupal weight of individuals that had undergone through five and

Table 1 - Percentage of components for the preparation of Greene et al. (1976) and Poitout \& Bues (1974)'s artificial diets.

\begin{tabular}{|c|c|c|c|}
\hline Component & Commercial brand & Greene et al. (1976) & Poitout \& Bues (1974) \\
\hline Distilled water (mL) & - & 79.87 & 77.95 \\
\hline Bacteriological agar (g) & Vetec $^{\mathrm{TM}}$ & 1.08 & 1.83 \\
\hline Bean - dry $(g)$ & Kicaldo $^{\circledR}$ - Branco, classe 1 & 5.87 & - \\
\hline Toasted wheat germ (g) & Frutos da Terra ${ }^{\circledR}$ & 4.70 & 3.21 \\
\hline Soybean protein $(\mathrm{g})$ & PTS Miúda Clara - Frutos da Terra ${ }^{\circledR}$ & 2.35 & - \\
\hline Casein $(g)$ & P.A. - Dinâmica ${ }^{\circledR}$ & 1.75 & - \\
\hline Yeast extract $(\mathrm{g})$ & $\mathrm{Kasvi}^{\circledR}$ & 2.93 & 3.43 \\
\hline Ascorbic acid (g) & P.A. - Dinâmica ${ }^{\circledR}$ & 0.28 & 0.45 \\
\hline Vitamin mixture (Vanderzant) & Manipulate by Farmacotécnica $\left(^{*}\right)$ & 0.50 & - \\
\hline Tetracycline Hydrochloride & Medquímica $^{\circledR}$ & 0.01 & - \\
\hline Formalin $(\mathrm{mL})-$ diluted on distilled water & P.A. Proquimios ${ }^{\circledR}$ & 0.28 & 0.05 \\
\hline Methyl P-hydroxybenzoate (g) & P.A. - Dinâmica ${ }^{\circledR}$ & 0.24 & 0.11 \\
\hline Sorbic acid $(\mathrm{g})$ & P.A. - Dinâmica ${ }^{\circledR}$ & 0.14 & - \\
\hline Cornflour (g) & Variety Embrapa BRS $4103^{* *}$ & - & 12.84 \\
\hline Benzoic acid $(\mathrm{g})$ & P.A. Vetec ${ }^{\mathrm{TM}}$ & - & 0.13 \\
\hline
\end{tabular}

* each gram contends: Niacinamide $(2.000 \mathrm{mg})$, calcium pantothenate $(2.000 \mathrm{mg})$, Thiamine $\mathrm{HCl}(0.500 \mathrm{mg}), \mathrm{Riboflavin}(1.000 \mathrm{mg})$, Pyridoxine $\mathrm{HCl}(0.500 \mathrm{mg})$, Folic acid $(0.500 \mathrm{mg})$, Biotin $(0.040 \mathrm{mg})$, Vitamin B12 (0.004mg), plus inert.

tamanho máximo dos grãos $1.18 \mathrm{~mm}$. 
six instars were compared with the Wilcoxon's nonparametrical test at $5 \%$ probability. The following reproductive parameters from adults were considered: fecundity (number of eggs per female), fertility (number of larvae per female), and pre- and post- oviposition periods (days). From the immature and adult data, fertility life tables were elaborated to represent graphically the probability of survival values (survival rate $-1 \mathrm{x}$ ) and the number of eggs oviposited per female (specific fertility - $\mathrm{mx}$ ) by week. The average generation time (T), liquid reproduction rate (Ro), intrinsic increase rate $(\mathrm{Rm})$, and finite increase ratio $(\lambda)$ were estimated (SILVEIRA NETO et al., 1976).

\section{RESULTS}

The population larvae of E. agrotina reared on the Greene's diet declined and has died out completely by the third generation of the colony. Larvae from the colony reared on Poitout \& Bues's diet continued for five generations, with increasing insect number, and no decrease in vitality.

The total survival of E. agrotina colony was higher under Poitout \& Bues's diet. On Greene's diet, the survival was very low percent was note, especially in the larval and egg stages (Table 2).

Comparisons among insects reared on Greene's diet presented with significant differences between the female and male adults that went through the fifth and sixth instars. All larvae reared on Poitout \& Bues's diet went through six instars. Nearly half of those reared on Greene's diets presented one less instar stage (Table 3).

Comparisons among caterpillars of the same sex that underwent six instars and were reared on Greene's and Poitout \& Bues's presented with significant differences in all instars. Duration of egg and larval stages of E. agrotina was significantly higher for larvae reared on Greene's diet (Table 2), for individuals with both five and six instars (Table 3 ). There were significant differences in the same gender pupae duration on individuals who went through the same number of instars. Regarding pupal weight, significant differences were observed when comparing diets (Greene's - $0.09 \pm 0.05 \mathrm{~mm}$; Poitout \& Bues's - 0.10 $\pm 0.01 \mathrm{~mm})(\mathrm{F}=0.13 ; \mathrm{P}<0.05)$ (Table 3$)$.

Longevity of adults from the colony reared on Poitout \& Bues's diet was significantly higher than of those reared on Greene's diet (Table 2 ), which can be explained by the longer longevity of male adults (Table 4). Even though there was no significant difference on female adult' longevity, significant longer oviposition and pre-oviposition periods of female adults the colony reared on Poitout \& Bues's diet. Fecundity and fertility followed the same pattern (Table 4). Insects reared on Greene's diet presented higher mean generation time $(\mathrm{T})$ and lower reproduction rates (Ro), intrinsic increase rate $(\mathrm{Rm})$ and finite increase ratio $(\lambda)$ than did the insects from colony reared on Poitout \& Bues's diet.

Figure 1 presents the differences between individuals from both colonies, considering their survival on immature stages and specific fertility. Overall, the oviposition peak occurred around the seventh day after eclosion.

\section{DISCUSSION}

Results of this study indicated the benefits of the Poitout \& Bues's diet when establishing an E. agrotina colony in laboratory. Insects under Poitout \& Bues's diet developed better and could be maintained through five generations. Results of

Table 2 - Viability (\%) and duration (days) of the Elaphria agrotina stages, with larvae reared on Grenee's and Poitout \& Bues's artificial diets $\left(25 \pm 1^{\circ} \mathrm{C}, 70 \pm 10 \% \mathrm{RH}\right.$ and 12 hour photophase).

\begin{tabular}{|c|c|c|c|c|}
\hline \multirow{2}{*}{$\begin{array}{l}\text { Diet } \\
\text { Stage }\end{array}$} & \multicolumn{4}{|c|}{--------------------------------Grenee------------------------------- } \\
\hline & Viability & Duration $(\mathrm{X} \pm \mathrm{SD})$ & Viability & Duration $(\mathrm{X} \pm \mathrm{SD})$ \\
\hline Egg & 30.98 & $3.79 \pm 0.46^{*}$ & 80.32 & $3.17 \pm 0.37$ \\
\hline Larval & 24.00 & $22.79 \pm 4.36^{*}$ & 97.00 & $19.00 \pm 2.16$ \\
\hline Prepupal & 100.00 & $4.18 \pm 2.01^{*}$ & 99.48 & $2.75 \pm 0.78$ \\
\hline Pupal & 75.00 & $9.83 \pm 2.75$ & 100.00 & $8.97 \pm 1.86$ \\
\hline Adult & - & $14.65 \pm 2.27^{*}$ & - & $15.92 \pm 1.55$ \\
\hline Overall & 5.57 & 55.24 & 77.51 & 49.81 \\
\hline
\end{tabular}

*Significance by the Wilcoxon test at the $5 \%$ probability level. 
Table 3 - Duration (days) and pupal weight (mg) of larvae of Elaphria agrotina fed with Greene's and Poitout \& Bues's artificial diets, considering the sex and number of larval instars $\left(25 \pm 1{ }^{\circ} \mathrm{C}, 70 \pm 10 \% \mathrm{RH}\right.$ and $12 \mathrm{~h}$ photophase).

\begin{tabular}{|c|c|c|c|c|c|c|}
\hline \multirow{3}{*}{$\begin{array}{l}\text { Diet } \\
\text { Instar }\end{array}$} & \multicolumn{4}{|c|}{ 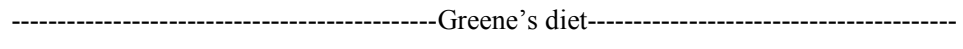 } & \multirow{2}{*}{\multicolumn{2}{|c|}{------Poitout \& Bues’s diet------ }} \\
\hline & \multicolumn{2}{|c|}{------------------Five instars-------------- } & \multicolumn{2}{|c|}{------------------Six instars---------------- } & & \\
\hline & Female (10) & Male (13) & Female (14) & Male (11) & Female (101) & Male (93) \\
\hline \multicolumn{7}{|c|}{ - } \\
\hline I & $3.00 \pm 0.95$ & $3.08 \pm 0.95$ & $3.64 \pm 0.63^{+}$ & $3.72 \pm 0.78^{+}$ & $2.28 \pm 0.68^{+}$ & $2.22 \pm 0.63^{+}$ \\
\hline II & $4.95 \pm 2.24$ & $5.31 \pm 2.52$ & $4.5 \pm 2.21^{+}$ & $5.63 \pm 1.02^{+}$ & $3.02 \pm 0.45^{+}$ & $3.18 \pm 0.74^{+}$ \\
\hline III & $3.86 \pm 1.05$ & $3.77 \pm 0.83$ & $3.71 \pm 1.32^{+}$ & $4.54 \pm 1.36^{+}$ & $3.17 \pm 0.95^{+}$ & $3.14 \pm 0.89^{+}$ \\
\hline IV & $3.43 \pm 1.44$ & $3.77 \pm 1.58$ & $4.07 \pm 1.59^{*}$ & $2.90 \pm 0.94^{*+}$ & $3.88 \pm 1.22$ & $3.75 \pm 1.11^{+}$ \\
\hline V & $4.86 \pm 3.12$ & $5.08 \pm 3.96$ & $4.64 \pm 1.39^{+}$ & $4.00 \pm 1.34$ & $3.55 \pm 1.11^{+}$ & $3.41 \pm 0.84^{+}$ \\
\hline VI & - & - & $4.21 \pm 2.04^{*}$ & $5.45 \pm 1.57^{*}$ & $3.22 \pm 0.99^{+}$ & $3.13 \pm 0.84^{+}$ \\
\hline Total & $19.00 \pm 3.97$ & $21.00 \pm 5.01$ & $24.78 \pm 2.08^{+}$ & $25.81 \pm 2.13^{+}$ & $19.15 \pm 2.33^{+}$ & $18.84 \pm 1.94^{+}$ \\
\hline Pre-pupae & $2.90 \pm 1.59$ & $3.76 \pm 2.12$ & $5.57 \pm 1.98^{+}$ & $4.09 \pm 1.30^{+}$ & $2.66 \pm 0.38^{+}$ & $2.83 \pm 0.77^{+}$ \\
\hline Total & $21.90 \pm 5.96$ & $24.76 \pm 6.61$ & $30.35 \pm 2.43^{+}$ & $29.90 \pm 2.54^{+}$ & $21.81 \pm 2.32^{+}$ & $21.67 \pm 2.04^{+}$ \\
\hline Pupae & $8.5 \pm 3.25$ & $8.90 \pm 4.15$ & $10.16 \pm 0.57^{*+}$ & $11.63 \pm 1.59^{*+}$ & $8.84 \pm 1.66^{+}$ & $9.15 \pm 2.04^{+}$ \\
\hline \multicolumn{7}{|c|}{ 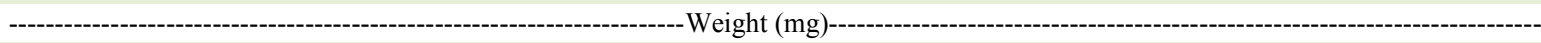 } \\
\hline Pupae & $0.09 \pm 0.01$ & $0.08 \pm 0.01$ & $0.09 \pm 0.06^{+}$ & $0.08 \pm 0.02^{+}$ & $0.10 \pm 0.01^{+}$ & $0.10 \pm 0.01^{+}$ \\
\hline
\end{tabular}

${ }^{*}$ Significance by the Wilcoxon test at $5 \%$ probability level for male and female adults raised on the same artificial diet. ${ }^{+}$Significance by the Wilcoxon test at 5\% probability level for sixth instar individuals of the same sex raised on the Greene's and Poitout \& Bues's diets.

differences between the two tested diets reinforce the importance of evaluating different artificial diets to optimize quality and vitality of the insects, allowing populations' maintenance for several generations and for across several biology and behaviour bioassays (PARRA, 2009; SCHNEIDER, 2009). One explanation for the success of the E. agrotina colony with the Poitout \& Bues's diet is the fact that the larva of this species has a preference for dry tissues and cereals, especially corn (SPECHT et al., 2014), which is the main component of this diet (POITOUT \& BUES, 1974).

However, even on Poitout \& Bues's diet, the E. agrotina development was relatively slow as compared to that of E. nucicolora (Guenée) (approximately 60 days) reared at $21.11^{\circ} \mathrm{C}$ with

Table 4 - Longevity, the pre-, post- and oviposition periods (days); fecundity and fertility; and reproductive parameters of Elaphria agrotina whose larvae were reared on Greene's and Poitout \& Bues's diet $\left(25 \pm 1^{\circ} \mathrm{C}, 70 \pm 10 \% \mathrm{RH}\right.$ and 12 hours of photophase).

\begin{tabular}{lccc}
\hline Larval diet & & Greene & Poitout \& Bues \\
\hline Sex & Parameter & Mean \pm SD & Mean \pm SD \\
\hline Female & Longevity (days) & $15.80 \pm 1.93$ & $16.5 \pm 1.76$ \\
& Pre-oviposition (days) & $4.3 \pm 0.57$ & $9.8 \pm 1.10^{*}$ \\
& Oviposition (days) & $4.60 \pm 3.10$ & $1.95 \pm 0.60^{*}$ \\
& Post-oviposition (days) & $0.80 \pm 0.42$ & $167.65 \pm 79.84^{*}$ \\
\hline & Fecundity (eggs) & $84.90 \pm 137.66$ & $134.65 \pm 64.25^{*}$ \\
\hline Male & Fertility (caterpillars) & $26.30 \pm 32.86$ & $15.35 \pm 1.08^{*}$ \\
\hline T & Longevity (days) & $13.51 \pm 1.96$ & 44.10 \\
Ro & - & 54.02 & 64.63 \\
Rm & - & 2.44 & 0.66 \\
$\lambda$ & - & 0.12 & 1.94 \\
\hline
\end{tabular}

*Significance by the Wilcoxon test at 5\% probability level. 


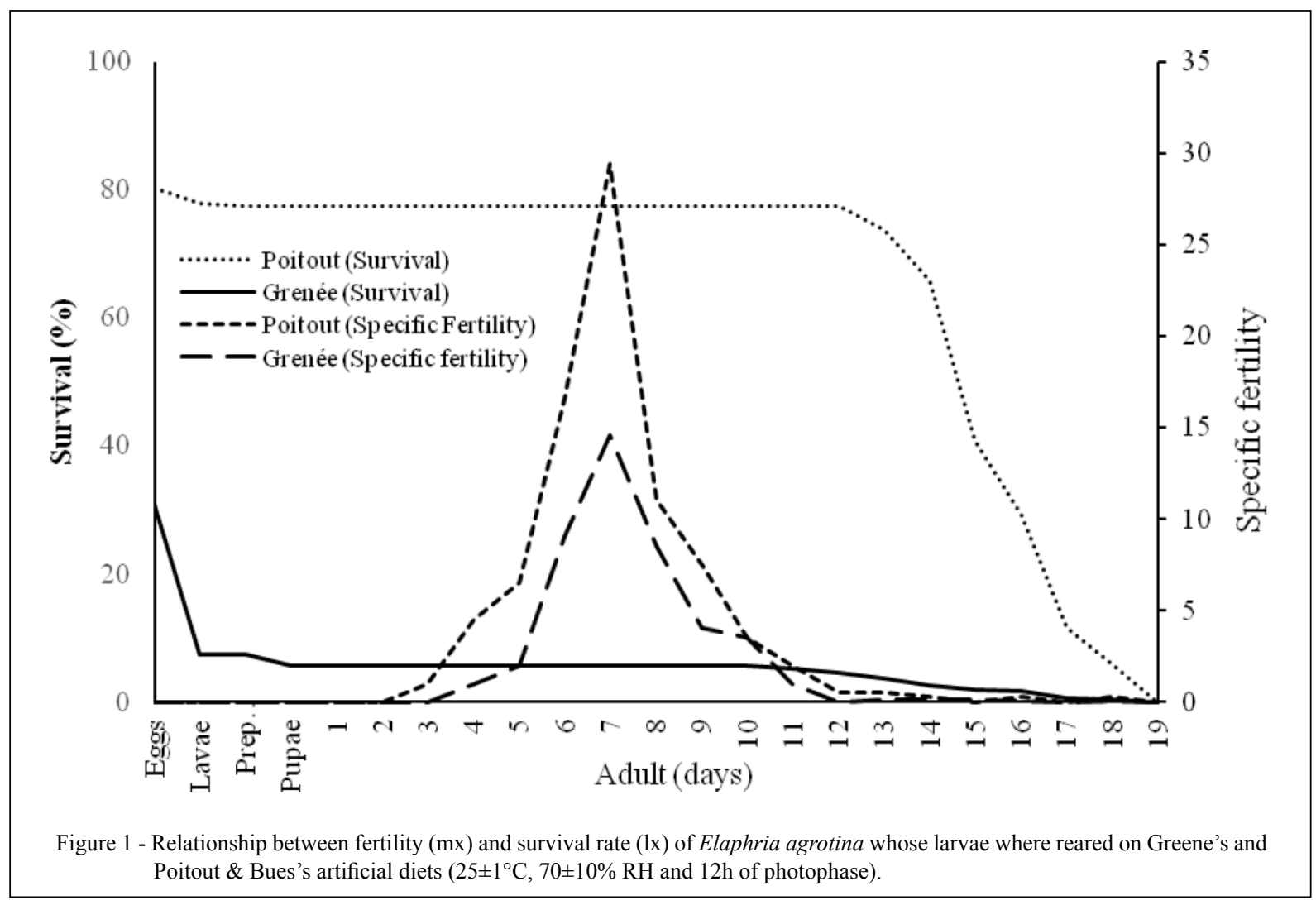

larvae reared on rape leaves (HABECK, 1965). The development time of this small species is even slower when compared to noctuids such as Spodotera albula (Walker), S. eridania (Stoll) and S. frugiperda (J.E. Smith) (BUSATO et al., 2006; MONTEZANO et al., $2013 ; 2014)$, which can complete their cycle in about a month and their pupae weight the double or triple when raised in similar temperature conditions.

An increase in the number of the instars is expected in lepidopterans (ESPERK et al., 2007) due to inadequacy of a diet. In the present study, E. agrotina colony reared on Greene's diet had only five instars. The same results were observed in some species, such as Psacothea hilaris (Pascoe) (Coleoptera: Cerambycidae), which presents a reduction of one instar stage under starvation condition (MUNYIRI et al., 2003). Reduction of one instar and the anticipated pupation with smaller size could benefit the species rather than extend its development in a hostile environment. Elaphria agrotina larvae has the same feeding behaviour as $P$. hilaris, which preferably feeds on dead tissues and survives close to dry plant tissues, such as straws in non-tillage systems, and on litter in a natural savannah (SPECHT et al., 2014).

Regarding the diets' composition, several aspects can influence the development of E. agrotina, including: water quantity, as the insect usually lives on less humid environments; fibers quantity, as chewing insects do not develop properly with low amount of fibers; reducing sugars, which is an important composition to the diet to provide energy; nitrogen derived from proteins, which are broken to obtain amino acids and smaller molecules that are used to build tissues and possess biological functions associated with vital activities; and lipids, which are used in cellular wall and membrane formation and production of hormones, transporters, energy and other molecules and structural components (COHEN, 2003; PARRA, 2009; SCHNEIDER, 2009).

The overall fecundity of E. agrotina was also reduced when compared to E. nucicolora, which can lay more than 900 eggs (HABECK, 1965) and other Noctuidae from the genus Spodoptera (e.g. BUSATO et al., 2006; MONTEZANO et al., 2013; 2014).

The colony of E. agrotina was kept in laboratory through five generations, without losing 
vitality. In addition, the larval survival was greater than $75 \%$, which is considered adequate for the establishment of insect' colonies in laboratory (SINGH, 1983; SCHNEIDER, 2009). The conclusion is that Poitout \& Bues's diet is adequate to maintain E. agrotina colony in laboratory.

\section{CONCLUSION}

Results presented in this study indicated that Poitout \& Bues's artificial diet is more appropriate to the maintenance of E. agrotina in laboratory than Greene's diet, due to its suitability for mass rearing aiming to obtain insects for bioassays and for the maintenance of multiple generations in the laboratory.

\section{ACKNOWLEDGMENTS}

The Fundação de Amparo a Pesquisa do Distrito Federal (FAPDF) for granting the master's degree scholarship. To research funding from Conselho Nacional de Desenvolvimento Científico e Tecnológico (CNPq) (proc. $n^{\circ}$. 403376/2013-0) and Empresa Brasileira de Pesquisa Agropecuária (Embrapa) (SEG MP2 $\mathrm{n}^{\circ}$ 02.13.14.006.00.00). To Instituto Chico Mendes (ICMBio), Ministério do Meio Ambiente do Brasil - Authorization for scientific activities SISBIO 38547/(1-6).

\section{DECLARATION OF CONFLICTING INTERESTS}

The authors declare no conflicting interests.

\section{REFERECES}

BUSATO, G.R. et al. Adequação de uma dieta artificial para biótipos "milho" e "arroz" de Spodoptera frugiperda (Lepidoptera: Noctuidae). Bragantia, v.65, p.317-323, 2006. Available from: <http://www. scielo.br/pdf/brag/v65n2/30493.pdf>. Accessed: Apr. 12, 2017. doi: 10.1590/S0006-87052006000200014.

BUTT, B.A.; CANTU, E. 1962. Sex determination of lepidopterous pupae. Washington: United States Departament of Agriculture-ARS, 1962. p.33-75.

COHEN, A.C. Insect Diets-Science and Technology. New York, CRC Press, 2 ed., 2003. 344p.

ESPERK, T. et al. Intraspecific variability in number of larval instars in insects. Journal of Economic Entomology, v.100, p.627-645, 2007. doi: 10.1603/0022-0493(2007)100[627: IVINOL]2.0.CO;2.

GALLO, D. et al. 2002. Entomologia agrícola. Piracicaba, FEALQ, 920p.

GREENE, G.L. et al. Velvetbean caterpillar: a rearing procedure and artificial medium. Journal of economic entomology, v.69, p.487-488, 1976. doi: 10.1093/jee/69.4.487.

HABECK, D.H. Laboratory culture and development in Elaphria nucicolora (Lepidoptera: Noctuidae). The Florida Entomologist, n.48, p.187-188, 1965. Avaliable from: <http://www.jstor.org/ stable/3493223 > . Accessed: Jan. 14, 2017. doi: 10.2307/3493223.

HEPPNER, J.B. Lepidoptera of Florida, Part 1: Introduction and Catalog. Arthropods of Florida and neighboring land areas. v.17, p. 1-670. 2007. Available from: <http://freshfromflorida.s3.amazonaws. com/arthropods-of-florida-vol-17.pdf $>$. Accessed: Jan. 11, 2017.

MONTEZANO, D.G. et al. Biotic potential and reproductive parameters of Spodoptera eridania (Stoll) (Lepidoptera, Noctuidae) in the laboratory. Revista Brasileira de Entomologia, v.57, p.340-345, 2013. Available from: <http://www.scielo.br/pdf/rbent/v57n3/aop2613.pdf >. Accessed: Dez. 10, 2016. doi: 10.1590/S0085-56262013005000026.

MONTEZANO, D.G. et al. Biotic potential, fertility and life table of Spodoptera albula (Walker) (Lepidoptera: Noctuidae), under controlled conditions. Anais da Academia Brasileira de Ciências, v.86, p. 723-732, 2014. Available from: <http://www. scielo.br/pdf/rbent/v57n3/aop2613.pdf>. Accessed: Jan. 24, 2017. doi: 10.1590/0001-3765201402812.

MUNYIRI, F.N. et al. Threshold weight for starvation-triggered metamorphosis in the yellow-spotted longicorn beetle, Psacothea hilaris (Coleoptera: Cerambycidae). Applied Entomology and Zoology, v.38, p.509-515, 2003. doi: 10.1303/aez.2003.509.

PARRA, J.R.P. A evolução das dietas artificiais e suas interações em ciência e tecnologia, in: PANIZZI, A.R; J.R.P. PARRA (Eds.) Bioecologia e nutrição de insetos: Base para o manejo integrado de Pragas. Brasília: Embrapa 2009. P.91-174.

POITOUT, S \& BUES, R. Élevage de chenilles de vingthuit espèces de lépidoptères noctuidae et de deux espèces d'artctiidae ser milieu artificiel simple. Particularités de l'élevage selon les espèces. Annales de Zoologie, Écologie Animale, v.6, p.431-441, 1974.

SINGH, P. A general purpose laboratory diet mixture for rearing insects. Insect Science and Its Application. v. 4, p. 357-362, 1983. doi: 10.1017/S1742758400002393.

SILVEIRA NETO, S. et al. Manual de ecologia dos insetos. Piracicaba - SP: Agronômica Ceres, 1976. 419 p.

SCHNEIDER J, 2009. Principles and procedures for rearing high quality insects. Mississippi State University, Starkville. 352 pp.

SPECHT, A. et al. Noctuídeos (Lepidoptera, Noctuidae) do Museu Entomológico Ceslau Biezanko, Faculdade de Agronomia Eliseu Maciel, Universidade Federal de Pelotas, RS. Revista Brasileira de Agrociência, v. 10, p.389-409, 2004. Available from: $<$ https://periodicos.ufpel.edu.br/ojs2/index.php/CAST/article/ view/985/916>. Accessed: Nov. 12, 2016. doi: 10.18539/cast. v10i4.985.

SPECHT, A. et al. First report of Elaphria agrotina and Elaphria deltoides (Lepidoptera: Noctuidae: Elaphriini) feeding on maize. Journal of Economic Entomology, v.107, p.1458-1461, 2014. doi: $10.1603 / \mathrm{EC} 14101$.

TARRAGÓ, M.F.S. et al. Levantamento da família Noctuidae através de armadilhas luminosas, em Santa Maria, RS. Revista do Centro de Ciências Rurais, v.5, p.125-130, 1975. Available from: <http:// coral.ufsm.br/revistaccr/index.php/RCCCR/article/view/138/139>. Accessed: Feb. 02, 2017. 